\title{
Customer Process Management: A Systematic Literature Review
}

\author{
Feliks Prasepta Sejahtera Surbakti ${ }^{1}$ \\ ${ }^{1}$ Industrial Engineering Department, Faculty of Engineering, Atma Jaya Catholic University of Indonesia, Jakarta, \\ Indonesia \\ Correspondence: Feliks Prasepta Sejahtera Surbakti, Faculty of Engineering, Unika Atma Jaya Jakarta, Indonesia, \\ Jl. Jend.Sudirman No.51, Jakarta, Indonesia. Tel: 61-21-570-8826. E-mail: feliks.prasepta@atmajaya.ac.id
}

Received: June 4, 2015

doi:10.5539/emr.v4n2p1

\author{
Accepted: July 2, 2015 \\ Online Published: August 29, 2015 \\ URL: http://dx.doi.org/10.5539/emr.v4n2p1
}

\begin{abstract}
Customer Process Management (CPM) is not a new term. This phrase has been emerged in academic article since 1999. The CPM expression has received increasing attention from researcher, consultants, practitioner from technology and application firms. The consultants and practitioners introduced customer process management software during 2003-2008 since most Customer Relationship Management (CRM) initiatives failed. The following years, CPM attracted less attention from academics as well as practitioners, until Prof. Michael Rosemann in 2014, a Business Process Management (BPM) leading expert, called for new BPM research directions. One of his suggestions was to conduct research in CPM, which will complement the dominating current view of BPM. To the best of our knowledge, there is no literature review article to examine CPM. Therefore, the research question of this paper: What is the current state-of-the-art research on CPM in academic literature? This research questions will be breakdown into two research objectives. First, present an overview of existing academic literature on CPM. Second, develop potential topics for future research in this field. The results of this study show that there are many opportunities to conduct research in this area.
\end{abstract}

Keywords: customer process management, business process management, systematic literature review

\section{Introduction}

The term "Customer Process Management" (CPM) began to appear more or less 10 years ago. The articles from consultants and practitioners of technology and application firms emerged simultaneously (Fingar, 2003; Ventana research, 2006). The background of the emerged of this term was because of Customer Relationship Management (CRM) failure. Gartner, Inc., the world's leading information technology research and advisory company, revealed two-thirds of CRM initiatives failed (Fingar, 2003). Some of leading information technology and application firms modified their CRM software at that time. They called the concept underpinning their new application was customer process management and named their application customer process management software.

After a decade, CPM atrracted less attention from academics as well as practitioners, until Rosemann (2014), a Business Process Management (BPM) leading expert, called for new BPM research directions. One of his suggestion was to conduct research in CPM, that will complementing the dominating inside-out view of BPM (exploitative BPM) with outside-in view of BPM (explorative BPM). The meaning of inside-out view of BPM was current BPM focus on efficiency, such as eliminate waste, reduce variation (product defect), debottlenecking, downsizing and focus on their internal business process: procurement, production, marketing, finance, human resource management. Rather than the traditional, provider-centric view and problem-focused, CPM is opposed to that. CPM is customer-centric view and opportunity-focused. The best explanation to CPM is described by Potts (2012): "It is not about how customers participate in our (business) process, but about how we participate in the customer's processes."

CPM is also the antithesis of CRM and BPM, where until now business process mostly represents commoditized "best practices". Customers demand custom products and services and they also demand customized business process that serve their unique demand. In the era of mass customization and personalization, unique end to end business process may be needed for just a single customer and a single transaction. Others may serve multiple customers over long periods of time. A typical company will need to manage both kinds of business process. As a result, customer process management must be taken into account. 
To the best of our knowledge, there is no literature review to examine CPM. The purpose of this paper is to provide an overview of existing research on CPM. In this paper we examine the evolution of the CPM in academic literature. The evolution of the literature in this topic is discussed and a research agenda is proposed. The research question: What is the current state-of-the-art research on CPM in academic peer-reviewed literature? This research questions will be breakdown into two research objectives. First, present an overview of existing papers on CPM. Second, develop potential topics for future research in this new field.

This paper reviewed customer process management-contained word research articles for their research objective, methodology, author country, years of publication. Although customer process management has been recognized by academics and practitioners, researchers have not systematically employed customer process management in BPM or other related field. This literature review provides a basis of reference that can be used for further research regarding CPM in BPM. As far as I concern, this is the first paper that can guide practice and further theory development and empirical research. The paper will be valuable to scholars working in the field of business process management and service science, who interested in the literature evolution and in identifying future research area.

This paper aims to conduct a systematic literature review of customer process management which indexing by Google Scholar, proquest and many other databases. We used keyword "customer process management" as a search queries. The structure of this paper is designed in the following way. First, we search for the CPM literature in academic articles. Second, we discuss the results and identify the limitation of the literature review, and identify the areas for future research. Finally, the paper concluded with conclusion and recommendation.

\section{Method}

The research method of literature study is intended as a guide, to help systematize the reviewing process for a more optimal outcome that contributes to theoretical progress. This research method is iterative in nature. This approach can be used for many different types of literature review. The research method start from defining research objective, define the criteria for inclusion and exclusion, identify the fields of research, determine the appropriate sources, decide on the specific search term, search, refine the sample, discussion, and present the conclusion (Webster \& Watson, 2002). The research method of this research can be seen in Figure 1. This research objective is to present an overview of existing academic literature on CPM and to develop potential topics for future research.

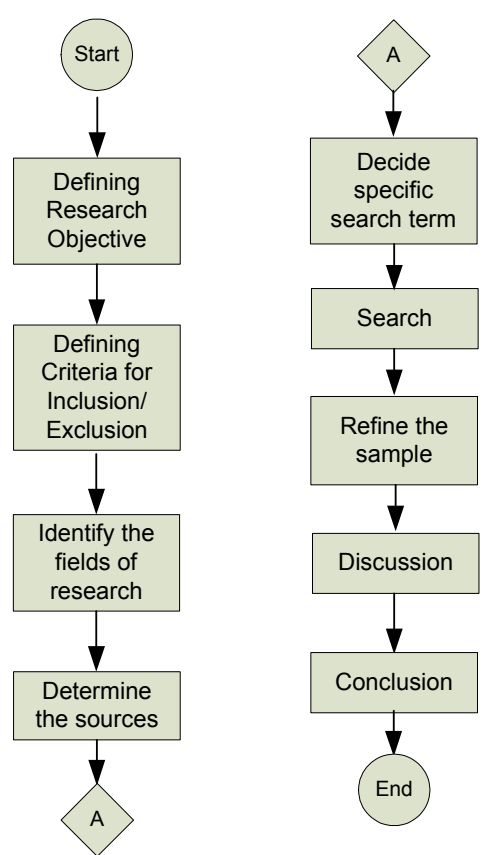

Figure 1. Research method

The purpose to define the criteria for inclusion and/or exclusion of an article in the dataset is to efficiently perform a systematic literature research. This first task involves marking out the scope of the review as well as inclusion and exclusion criteria. The first exclusion criteria were we limit our investigation to peer-reviewed 
journal and conference articles, excluding books and other published materials. We only consider peer-reviewed articles with the purpose of giving credibility to the research. The literature review will not be effective if the literature gathered by the researcher is of low quality, incomplete or irrelevant (Levy \& Ellis, 2006). Typically, sources other than peer-reviewed journal and conference articles and book chapters are not seen as acceptable data for a scholarly review.

The next step, appropriate fields of research should be identified. We identified some different disciplines, i.e. marketing, service science, information systems, business and management. In order to optimize the actual finding of the desired texts in the fields, the outlets and databases are selected. Primary databases searched for the papers were Google scholar, ABI Inform/Proquest, Springer Link, EBSCO, Science Direct, JSTOR, Elsevier (scopus), IEEE Xplore, ACM Digital Library and Web of Knowledge database. To decide on the specific search term, we using only one keyword "customer process management" contained either in title, abstract, keywords or full paper in order to narrowing this research.

We conducted a search for articles with titles, abstracts, keywords or full paper containing the terms "Customer Process Management" through all the identified databases sources. First, Google scholar is used to search for peer-reviewed research papers. Google scholar is now considered sufficiently robust that other commonly used applications such as "Publish or Perish" are built on it (Bandara et al., 2011). When "customer process management" keyword was used, only 6 peer-reviewed journal and conference articles appeared. Then, we do not limit to the peer-reviewed journal, the result was 10 peer-reviewed journal and conference articles as well as book, book chapter appeared. These articles were downloaded and studied to explore various research issues in CPM.

Afterwards, we searching in ABI Inform/Proquest database and the result using keyword "customer process management" and we found 4 papers, which are also the same articles in Google Scholar. Third, we search in Springer Link with keyword "customer process management" we found 2 papers. The searching with EBSCO database, we found 2 articles. We found 1 article in Science Direct database and JSTOR database; zero result in Elsevier (scopus), IEEE Xplore, ACM Digital Library and Web of Knowledge database. Based on this result, a discussion and future research recommendation is developed.

\section{Results}

These days, the most economic and effective way to carry out research is through the use internet and databases. However, there is so much proliferation of information, effective and non-effective, authenticated and non-authenticated, reliable and non-reliable, and most importantly useful and non-useful. Therefore, Google Scholar is used to start the search for quality research papers. Initially "customer process management" was used as the search keyword. Some papers were downloaded but soon it was realized that most of the papers, but not all not connected to CPM. It was observed that many of these papers, although Google Scholar results for CPM keyword, completely do not have a word CPM at their articles. Following selection of the papers, it was found 10 articles from peer-reviewed journal, conference and book chapter.

It was found that 7 book chapters, 4 written in German and 3 in English From the springer link database, using keyword "customer process management". From 3 book chapters in English only 2 articles discuss the customer process management topic, which are Ouyang and Jung (2014), "Proposals for Future BPM Research Directions", and Van den Bergh et al. (2014) "Ambidextrous BPM: Making BPM Exciting Again—An Interview with Prof. Michael Rosemann". The other articles do not discuss customer process management at all.

It was observed that 7 results from the proquest database, using keyword "customer process management" and research for peer-reviewed articles. Moreover, only 3 articles using the term customer process management in their papers, which is Trkman et al. (2015), "From business process management to customer process management", Prajogo et al. (2012), "The effect of different aspects of ISO 9000 implementation on key supply chain management practices and operational performance", Kohlborn et al. (2014), "Interview with Michael Rosemann on ambidextrous business process management".

As shown in Table 1, there are 10 articles from peer-reviewed journal, conference and book chapter. The origin of that paper came from various countries, three from Australia, two from Germany and Belgium, one from Slovenia, Liechtenstein, China, Korea, Saudia Arabia, UK and USA. It can be said that the authors spread around the world and can be concluded that this term not specifically belonging to certain countries. The profiles of articles source came from 6 journals, 1 conference and 3 book chapters. The year of publication was starting from 1999 until 2015. From Table 1, we can draw a conclusion that CPM get more attention from researcher in recent years, about $90 \%$ articles came from 2010-2015. Based on the articles source, we can see that this topic came from multi disciplines: business process management, business informatics, business and management, 
manufacturing and sustainability, supply chain management, social science and marketing.

Table 1. Customer process management literature review

\begin{tabular}{|c|c|c|c|c|c|c|}
\hline No & Author(s)/Editor(s) & Year & Country & $\begin{array}{l}\text { Type of } \\
\text { Source }\end{array}$ & Source & Title \\
\hline 1 & Trkman et al. & 2015 & $\begin{array}{l}\text { Slovenia, } \\
\text { Australia, } \\
\text { Belgium }\end{array}$ & $\mathrm{J}$ & $\begin{array}{l}\text { Business Process } \\
\text { Management } \\
\text { Journal }\end{array}$ & $\begin{array}{l}\text { From business process management to } \\
\text { customer process management }\end{array}$ \\
\hline 2 & Kohlborn et al. & 2014 & $\begin{array}{l}\text { Australia, } \\
\text { Liechtenst } \\
\text { ein, } \\
\text { Germany }\end{array}$ & $\mathrm{J}$ & $\begin{array}{l}\text { Business Process } \\
\text { Management } \\
\text { Journal }\end{array}$ & $\begin{array}{l}\text { Interview with Michael Rosemann on } \\
\text { ambidextrous business process } \\
\text { management }\end{array}$ \\
\hline 3 & Ouyang \& Jung & 2014 & Australia & $\mathrm{B}$ & $\begin{array}{l}\text { Book Chapter Asia } \\
\text { Pacific Business } \\
\text { Process } \\
\text { Management }\end{array}$ & $\begin{array}{l}\text { Proposals for future BPM research } \\
\text { directions }\end{array}$ \\
\hline 4 & Bergh et al. & 2014 & Belgium & B & $\begin{array}{l}\text { Book Chapter } \\
\text { Transforming } \\
\text { Through Processes }\end{array}$ & $\begin{array}{l}\text { Ambidextrous BPM: Making BPM } \\
\text { Exciting Again-an interview with } \\
\text { Prof.Michael Rosemann }\end{array}$ \\
\hline 5 & $\begin{array}{l}\text { Moormann } \\
\text { Palvolgyi }\end{array}$ & 2013 & Germany & $\mathrm{C}$ & $\begin{array}{l}\text { IEEE International } \\
\text { Conference on } \\
\text { Business } \\
\text { Informatics }\end{array}$ & $\begin{array}{l}\text { Customer-centric business modelling : } \\
\text { setting a research agenda }\end{array}$ \\
\hline 6 & Kipesha & 2013 & China & $\mathrm{J}$ & $\begin{array}{l}\text { European Journal of } \\
\text { Business and } \\
\text { Management }\end{array}$ & $\begin{array}{l}\text { Performance of Microfinance } \\
\text { Institutions in Tanzania: integrating } \\
\text { financial and non financial metrics }\end{array}$ \\
\hline 7 & Kim et al. & 2013 & Korea & B & $\begin{array}{l}\text { Book Chapter } \\
\text { Reengineering } \\
\text { Manufacturing for } \\
\text { Sustainability }\end{array}$ & $\begin{array}{l}\text { An evaluation scheme for } \\
\text { product-service system models with a } \\
\text { lifecycle consideration from customer's } \\
\text { perspective }\end{array}$ \\
\hline 8 & Prajogo et al. & 2012 & Australia & $\mathrm{J}$ & $\begin{array}{lr}\text { Supply } & \text { Chain } \\
\text { Management: An } \\
\text { International } \\
\text { Journal }\end{array}$ & $\begin{array}{l}\text { The effects of different aspects of ISO } \\
9000 \text { implementation on key supply } \\
\text { chain management practices and } \\
\text { operational performance }\end{array}$ \\
\hline 9 & Hoda & 2012 & $\begin{array}{l}\text { Saudi } \\
\text { Arabia }\end{array}$ & $\mathrm{J}$ & $\begin{array}{l}\text { Social Science } \\
\text { Research Network }\end{array}$ & $\begin{array}{l}\text { CRM Implementation : Critical Success } \\
\text { Factors }\end{array}$ \\
\hline 10 & Achrol \& Kotler & 1999 & USA & $\mathrm{J}$ & $\begin{array}{l}\text { Journal } \\
\text { Marketing }\end{array}$ & Marketing in the network economy \\
\hline
\end{tabular}

\section{Discussion}

This research found 10 academic articles contained phrase "customer process management". This articles follow will review and discuss those papers chronologically. The term CPM has been used since 1999, in Journal of Marketing. One of the authors is marketing guru, Phillip Kotler. Customer process management appeared just once in that paper. It was one of three core marketing process: consumer management (to replace brand management), customer process management (to replace the sales function), and supply management (to replace logistics). After a decade, this term appeared again in 2010. The term customer process management in Hoda (2010) came just once. It appeared as a proposal that CRM solution buyers should evaluate CRM capabilities using a customer process management perspective. The company must invest over time in upgrades to process the technology. This requires focusing on customer process optimization.

The term customer process management was discussed thoroughly in 2012. Customer process management was 
a one of measurement variables in Prajogo et al. (2012). The results of this research was supportive implementation is positively related to internal and customer process management but customer process management has no significant impact on operational performance. In this paper, customer process management was a part of supply chain activities. According to the definition of Supply Chain Management (SCM), supply chain activities include internal process management as well as external supplier and customer process management. Customer process management includes activities relating to customer needs, customer service, customer complaints, customer feedback, customer satisfaction and customer confidence.

The focus of this research (Prajogo et al., 2012) was to evaluate the impact of ISO 9000 implementation on customer process management. The proposed hypothesis and results were basic implementation has a positive relationship with customer process management (rejected), advanced implementation has a positive relationship with customer process management (supported), supportive implementation has a positive relationship with customer process management (supported) and customer process management has a positive relationship with operational performance (rejected). Customer process management was measured using five items: establishing schemes for obtaining feedback from customers, enhancing customer service and complaint handling, enhancing customer satisfaction and reducing disputes/complaints, enhancing confidence of customers towards our company's capability and enhancing the understanding of customer needs.

The term customer process management appeared four times in 2013. Customer process management term appear just once in Kim et al. (2013) on introduction section, at a sentence that state building closer relations based on customer process management enables companies to anticipate future businesses and to stabilize the profit mechanism. Moormann and Palvolgyi (2013) see the idea that customer needs should be the starting point for designing business models becomes increasingly accepted. This paradigm shift towards a customer-centric perspective opens up a highly relevant field of research. In this paper their present a research agenda which contributes to the development of approaches for the identification of customer needs and for the setup of customer-centric business models. The term customer process management appeared once, as a direction for the companies to move from customer process support to customer process management. The term customer process management also appeared once in Kipesha (2013). He quoted Kaplan and Norton (2004) that internal business process perspective is includes operation process management, customer process management, innovations process management, and regulatory and social process management.

Customer process management appeared three times in 2014. First, Ouyang and Jung (2014) book chapter include Professor Michael Rosemann's article. This article proposes three future research and development directions for BPM academics and professionals, one of them customer process management. He proposes that customer process management complement the dominating internal view of business process management with a stronger, design-inspired view on the process experiences of customers. Customer process management is the ultimate form of an outside-in view on BPM. Building a design-led process innovation capability will allow crafting processes tailored to the desired experiences of customers. He also proposes that going beyond individual providers, might even lead to semi-automated customer processes in which not the customer, as at the moment, but customer process management solutions will take over parts of the orchestration. The demand of such solutions will increase with the extent to which such processes are regulated.

Van den Bergh et al. (2014) include book chapter with title Ambidextrous BPM: Making BPM Exciting Again An interview with Prof. Michael Rosemann. He proposes to help usher in this next phase of business process management, customer process management as a way of tapping into private processes with value-adding services. The better these services blend in with a customer's private processes, the better they will be received. In other words, the birth-to-date value chain as the ultimate business process and the ultimate form of customer-centered process design. Kohlborn et al., (2014) wrote a viewpoint paper. The purpose was getting an assesment of what BPM has been able to achieve so far, what promises have been fulfilled, and where BPM should be heading in the future. The authors conducted an interview with Professor Michael Rosemann, one leading expert in the BPM area, who shared his thoughts on ambidextrous BPM. In this paper, the word customer process management appeared once, as area of expertise of Professor Michael Rosemann.

In this year, the term customer process management appeared once. Trkman et al. (2015) discussed the shift from business process management to customer process management for the customer focused organization. The aim of this article is to propose that in order to achieve customer focus through BPM, companies should obtain the in-depth understanding of customer's processes and process improvement not only the interactions with but also the process of their customers. A case study on a large multinational company was conducted. The research found the method that was employed by the case organization consisted of combining BPM with service blueprinting, and of extending these efforts by integrating the customers' internal process into the scope of 
improvement. The value of this paper was the application of service within BPM research and practice to achieve customer centric organization.

There is only few peer-reviewed research paper discussed customer process management (CPM), despite of the fact that this topic is not new. This term has been used since 1990. It means this term attract no attention from researchers and practitioners. It is peculiar because many research about customer focused as well as process management, but only few research papers pertain to CPM. Service management has been the focus of CPM research. There is lack of standard CPM process or framework.

In summaries, from 10 articles, only 3 articles discussed customer process management profoundly. Prajogo et al. (2012) developed a latent variable called customer process management with 5 manifest variables. Ouyang and Jung (2014) took an interview with Prof. Michael Rosemann and he suggested the need to research and developed customer process management to extend current business process management. Trkman et al. (2015) proposed the combination of BPM with service blueprinting, and of extending these efforts by integrating the customers' internal process into the scope of improvement. In order to achieve customer focus through BPM, companies should obtain the in-depth understanding of customer's processes and process improvement not only the interactions with but also the process of their customers.

\section{Conclusion}

This paper carried out a literature review highlighting the state-of-the-art of CPM research. Moreover, in order to review CPM literature, the main papers of CPM in the last 10 years have been discussed chronologically so as to depict the evolution of the research field. The result extends the multi-disciplinary of CPM, and it is expected that the exploration of these topics will play an important role in further research. Last, the literature review highlighted a "first generation" of academician articles summary, which gave start to CPM future research. Today, a "second generation" of researchers seems to emerge, and therefore the authors expect that CPM research will continue its rapid path of evolution and diffusion.

The customer process management discussed in the previous section was summarized as follows: only 3 papers discussed customer process management thoroughly: Trkman et al. (2015), Ouyang and Jung (2014) and Prajogo et al (2012). Trkman et al. (2015) develop customer process management modeling for improvement. Ouyang and Jung (2014) conducted interviewing with Prof. Michael Rosemann and he proposed to more research and development on customer process management as an extended version of business process management, to more customer centric organization. Whereas Prajogo et al. (2012) used customer process management as a research variable, defined and measured it. The results of the literature review reveal a certain growing of the literature related to customer process management and a significant lack of BPM literature discussing CPM. Finally the paper argues the development and evolution of the research field that is now entering a phase of new directions. These new directions can be conceptualized in three ways - by context, by theme and by challenge.

\section{Research Limitation}

There are some limitations to the research methodology. The first limitation was the availability of the papers to the authors. Primary databases searched for the papers were Google scholar, ABI Inform/Proquest, Springer Link, EBSCO, Science Direct, JSTOR, Elsevier (scopus), IEEE Xplore, ACM Digital Library and Web of Knowledge database. It is possible there are another articles discussing CPM but not cited to the databases mention before. Secondly, we conducted a search of the peer-reviewed and other academic papers in English language publications. Some academic paper actually found in Germany. The researcher who understand Germany could continue this research to discuss CPM more comprehensively. The last limitation was the time constraints. All articles were searched until May 2015.

\section{Future Work}

There are many opportunities for future research. Currently, research relating customer process management only appeared in three papers. This paper can be used as a reference for further research. Researcher who interest in survey research could continue Prajogo et al. (2012) study. The construct customer process management may be has the positive effect on customer satisfaction, customer loyalty, purchase intentions, revenue and other variables.

Researcher who interested in business process management can follow Prof. Michael Rosemann recommendation to conduct research in customer process management. Trkman et al. (2015) have conducted research in customer process modeling using service blueprinting. The same research also has been done by Hewing (2013). His research produced a so called business process blueprinting, a method for customer-oriented business process modeling. If we compare to business process management body of knowledge, business process 
modeling is a small part of business process management. Because this review and synthesis includes only articles from selected databases, additional studies should integrate books and other published materials and also journal in Germany, which some of literature review write in Germany.

Customer Process Management also very related to Customer Experience Management (CEM) and Customer -Dominant Logic (Sukwadi, 2015; Heinonen, 2010). Researcher with experience and expertice in this area can expand their topic to Customer Process Management. Furthermore this study could be extended of combined with research from other disciplines, such as design, information systems, organization theory, operations, public policy and strategy, and marketing. For future work, academics and practitioners can work together to develop Customer Process Management Body of Knowledge (CPMBoK).

\section{Acknowledgments}

The author is thankful to Mr. John Ericson for editing this paper.

\section{References}

Achrol, R. S., \& Kotler, P. (1999). Marketing in the network economy. The Journal of Marketing, 146-163.

Bandara, W., Miskon, S., \& Fielt, E. (2011). A systematic, tool-supported method for conducting literature reviews in information systems. In Proceedings of the 19th European Conference on Information Systems (ECIS 2011).

Fingar, P. (2003). The Death of CRM "Apps" and the Birth of Customer Process Management. Thought-Leadership Paper, Chordiant

Heinonen, K., Strandvik, T., Mickelsson, K. J., Edvardsson, B., Sundström, E., \& Andersson, P. (2010). A customer-dominant logic of service. Journal of Service Management, 21(4), 531-548.

Hewing, M. (2013). Business Process Blueprinting: A Method for Customer-Oriented Business Process Modeling. Springer Science \& Business Media. http://dx.doi.org/10.1007/978-3-658-03729-1

Hoda, N. (2010). CRM Implementation: Critical Success Factors. Available at SSRN 2406488.

Kaplan, R. S., \& Norton, D. P. (2004). Strategy maps: Converting intangible assets into tangible outcomes. Harvard Business Press.

Kim, K. J., Lim, C. H., Heo, J. Y., Lee, D. H., Hong, Y. S., \& Park, K. (2013). An Evaluation Scheme for Product-Service System Models with a Lifecycle Consideration from Customer's Perspective. In Re-engineering Manufacturing for Sustainability (pp. 69-74). Springer Singapore.

Kipesha, E. F. (2013). Performance of Microfinance Institutions in Tanzania: Integrating Financial and Non financial Metrics. European Journal of Business and Management, 5(4), 94-105.

Kohlborn, T., Mueller, O., Poeppelbuss, J., \& Roeglinger, M. (2014). Interview with Michael Rosemann on ambidextrous business process management. Business Process Management Journal, 20(4), 634-638. http://dx.doi.org/10.1108/BPMJ-02-2014-0012

Levy, Y., \& Ellis, T. J. (2006). A Systems Approach to Conduct an Effective Literature Review in Support of Information Systems Research. Informing Science Journal, 9, 181-212.

Moormann, J., \& Palvolgyi, E. Z. (2013, July). Customer-Centric Business Modeling: Setting a Research Agenda. In Business Informatics (CBI), 2013 IEEE 15th Conference on (pp. 173-179). IEEE.

Potts, C.: (2010). RecrEAtion: Realizing the Extraordinary Contribution of your Enterprise Architects. Technics Publications

Prajogo, D., Huo, B., \& Han, Z. (2012). The effects of different aspects of ISO 9000 implementation on key supply chain management practices and operational performance. Supply Chain Management: An International Journal, 17(3), 306-322.

Rosemann, M. (2014). Proposals for future BPM research directions. In Asia Pacific Business Process Management (pp. 1-15). Springer International Publishing.

Sukwadi, R. (2015). Utilizing Customer Experience Management Framework to Create a Delightful Service Experience. International Journal of Industrial Engineering and Management (IJIEM), 6(1), 29-42.

Trkman, P., Mertens, W., Viaene, S., \& Gemmel, P. (2015). From business process management to customer process management. Business Process Management Journal, 21(2), 250-266. http://dx.doi.org/10.1108/BPMJ-02-2014-0010 
Van den Bergh, J., Thijs, S., \& Viaene, S. (2014). Ambidextrous BPM: Making BPM Exciting Again-An Interview with Prof. Michael Rosemann. In Transforming Through Processes (pp. 53-55). Springer International Publishing. http://dx.doi.org/10.1007/978-3-319-03937-4

Ventana research. (2006). Customer Process Management, Developing best practices and metrics for a customer-centric operation.

Webster, J., \& Watson, R. T. (2002). Analyzing the Past to Prepare for the Future: Writing a Literature Review. Management Information Systems Quarterly, 26(2), xiii-xxiii.

\section{Copyrights}

Copyright for this article is retained by the author(s), with first publication rights granted to the journal.

This is an open-access article distributed under the terms and conditions of the Creative Commons Attribution license (http://creativecommons.org/licenses/by/3.0/). 